\title{
THE ECONOMIC COST OF SPECIES PRESERVATION: THE NORTHWESTERN NEVADA CUI-UI
}

\author{
Kambiz Raffiee, Yiqi Luo and Shunfeng Song*
}

\begin{abstract}
In the economics of biodiversity, the relevant policy question is the level of certainty of species survival, rather than the simplistic binary problem of species preservation or extinction. In this study models of cui-ui survival probability and economic cost of water transfer are developed to estimate the cost of an endangered species preservation: the Northwestern Nevada cui-ui fish. There is a cost of over 160 million dollars to increase the likelihood of cui-ui survival by 2 percent, from 53 to 55 . The cost increases to over 2 billion dollars to increase the likelihood of cui-ui survival by 22 percent, from 63 to 85 . These findings highlight the economic trade-offs associated with modifying the survival likelihood of an endangered species. These results also confirm quantitatively the biological fact that the survival uncertainty must explicitly enter any discussion of species preservation.
\end{abstract}

\section{INTRODUCTION}

Species preservation has always been a highly contentious policy issue, fueling debate among biologists, economists, and policy makers on two key questions: which species should we attempt to save and what means should we employ? The first question requires evaluation of a species' contribution to biodiversity and its ecosystem function. The second question involves analysis of economic trade-offs and costs of preservation efforts (Gowdy, 1997). Once a species is targeted as a particularly valuable component of diversity, the incremental costs to achieve a given likelihood (probability) of species survival becomes crucial. In addition to species preservation, economic and ecological losses of an ecosystem degradation is the other dimension of biodiversity (Kahn and Kemp, 1985).

This paper develops a conceptual framework for the evaluation of species survival and conservation efforts with uncertain outcomes. The model is applied for the case of the Northwestern Nevada cui-ui (pronounced as kee-wee) fish by deriving a marginal cost curve for its survival. Three models are used to estimate the economic cost of cui-ui preservation: (i) a cui-ui survival model, providing

\footnotetext{
*Professor of Economics, University of Nevada, Reno; Associate Research Professor, Desert Research Institute, and Associate Professor of Economics, University of Nevada, Reno, respectively. The authors gratefully acknowledge faculty research support provided by Wells Fargo (formerly the First Interstate) Bank of Nevada through the University of Nevada, Reno, Foundation. The authors would like to thank two anonymous referees for their helpful comments and suggestions. Any remaining errors are the responsibility of the authors.
} 
the probability of cui-ui survival as a function of water transfer, (ii) an input-output (IO) model, providing the output changes dollar value and employment changes of economic sectors in the region of the study due to water transfers, and (iii) a cost model of an endangered species preservation, relating the economic cost to secure a higher cui-ui survival probability.

The findings establish a positively sloped marginal cost curve of survival probability of cui-ui, confirming a trade-off between economic production and an endangered species preservation. These results suggest that the level of species survival certainty is the appropriate policy choice variable, rather than the simplistic binary problem of species preservation or extinction (Gowdy and McDaniel, 1995; Montgomery et al., 1994). Instead of measuring the cui-ui survival total cost, one should consider the incremental cost of preservation efforts.

The balance of this paper is organized as follows. The following section provides background on the cui-ui fish. Section III develops models to determine the economic cost of an endangered species preservation. Section IV presents the estimation results. Conclusions of the study are summarized in the final section.

\section{THE NORTHWESTERN NEVADA CUI-UI}

A fish endemic to Pyramid Lake, Nevada, cui-ui is currently listed as endangered by the federal government (Federal Register, March 11, 1967, p. 32). ${ }^{1}$ Though found only in Pyramid Lake (Scoppettone et al., 1986), it must leave the lake to spawn successfully in the lower Truckee River (Koch, 1973; Coleman et al., 1987). Dating back to the Miocene Age, the genus apparently was widespread in west of the Continental Divide at that time. All four recognized species within this genus are currently endangered (Scoppettone and Vinyard, 1991).

This long-lived omnivorous sucker has historically been the subject of an important fishery for the Pyramid Lake Paiute Tribe (LaRivers, 1962). Although inhabiting Pyramid and Winnemucca Lakes at the beginning of the twentieth century, the species was eliminated from Winemucca Lake when it dried in the 1930s following unrestricted diversion of water from the Truckee River. Cui-ui is now restricted to Pyramid Lake and the lower Truckee River. Pyramid Lake, a terminal lake, has its depth and water chemistry directly dependent on the relation of inflow to evaporation. Over the last 85 years, the level of water in the lake has declined by approximately 24 meters, as a direct result of water diversion from the Truckee River. If cui-ui is to survive, 


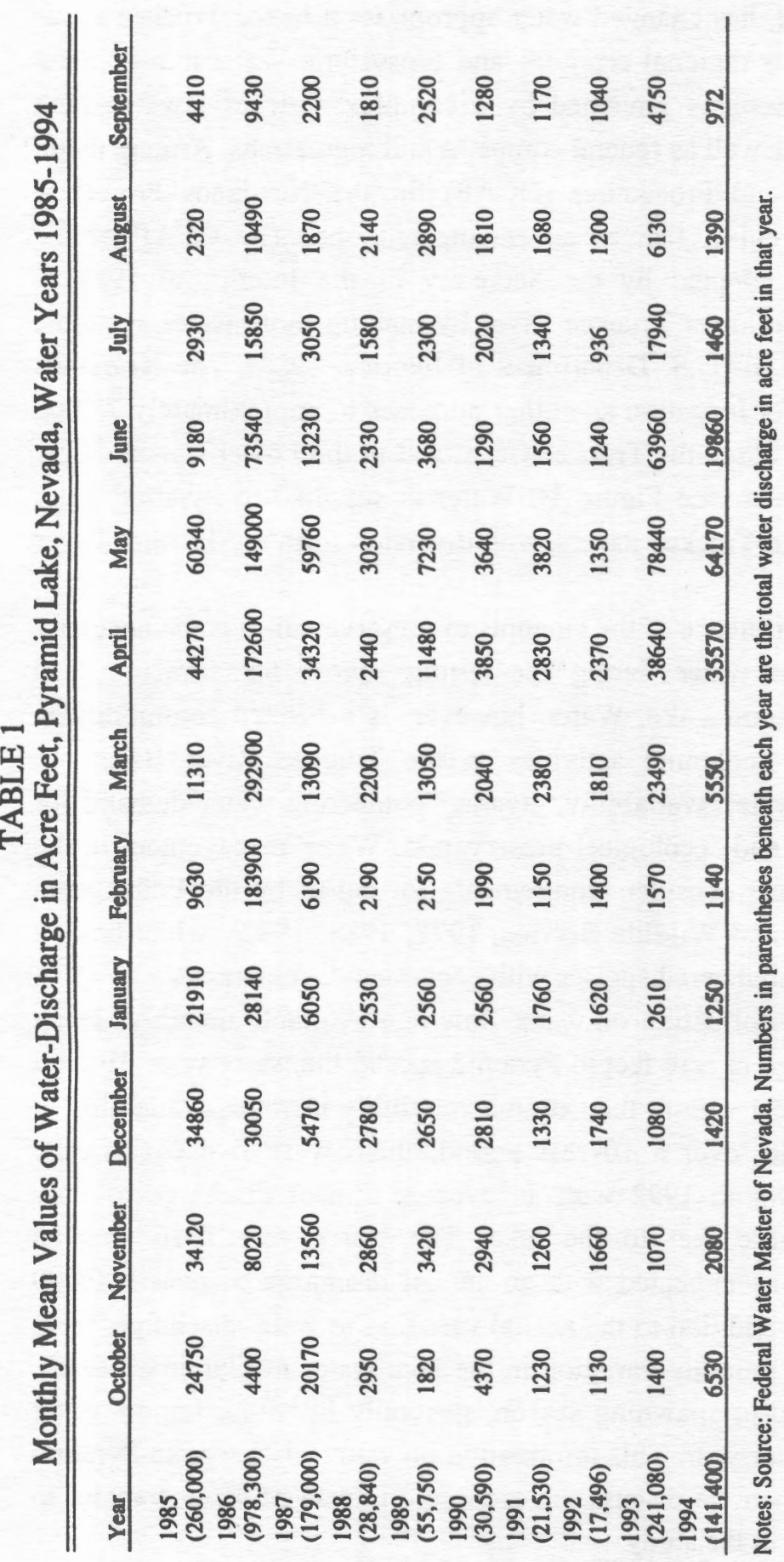


management of flows in the river must provide sufficient water to Pyramid Lake to stabilize lake elevation (U.S. Fish and Wildlife Service, 1992; 1983).

The 1967 listing of the fish, as an endangered species under the federal Endangered Species Act, has changed water appropriation in the Truckee River watershed, influencing its regional economy and ecosystem. Water management in the Truckee River basin is governed by a complex suite of laws in both California and Nevada as well as federal compacts and regulations. Among them, the Operating Criteria and Procedures (OCAP) for the Newlands Project is directly related to the cui-ui fish as an endangered one. The OCAP of the Newlands Project was adopted by the Secretary of the Interior in 1988 to maximize benefits in the lower Truckee River by making more water available during spawning by cui-ui (U.S. Department of Interior, 1988). The Newlands Project provides water for irrigation and other purposes to approximately 73,000 acres of land in Nevada along the Truckee Canal and in the Lower Carson River basin near Fallon, Nevada (see Figure 1). Water is supplied to Pyramid Lake from both the Carson and Truckee Rivers, with diversion from the Truckee River at Derby Dam.

The most evident influence of the attempts to preserve cui-ui is the necessity for providing sufficient water during the spring runoff for attracting and spawning flows in Pyramid Lake. Water, however, is a limited commodity in Northwestern Nevada. Economic activities in the Truckee River Basin are heavily dependent on water availability, creating competing water demand for economic development and ecological preservation. Water management in the Truckee River basin must consider requirements for cui-ui by the Endangered Species Act (U.S. Fish and Wildlife Service, 1977; 1983; 1992), while linking the preservation of an endangered species with economic development.

Table 1 provides information on water flow and available monthly mean values of water-discharge in acre feet to Pyramid lake in the water years 1985 to 1994. ${ }^{2}$ The data in Table 1 signify the extreme variability in water availability in the region. For example, over a 10 -year period, there were five consecutive drought years from 1988 to 1992 with an average annual discharge of only slightly over 30,000 acre feet to the lake. The water year 1986 was an exceptionally wet year as indicated with an annual discharge of over 900,000 acre feet to the lake. In addition to the annual variation in water discharge, there is also a wide range of monthly variation in the lake water availability. March, April, and May, the cui-ui spawning season, generally have the largest water discharge in a given water year. This information on water discharge to Pyramid Lake will be helpful when we discuss the economic impact of water transfer to cui-ui preservation later in the study. 


\section{COST MODEL OF AN ENDANGERED SPECIES PRESERVATION}

This section analyzes the trade-offs between economic costs and cui-ui survival probabilities in three steps. First, it examines the impact of water transfer on output of economic sectors in a region. Second, it presents a cui-ui survival probability model. Finally, it derives an economic cost function of cui-ui preservation using the relationship between water transfer and cui-ui survival probability.

\section{Water and Output Production}

Water is an important production input, i.e., $Q=f\left(W_{E}\right)$, where $Q$, measured in dollars, is the annual output produced by economic sectors in a region, and $W_{E}$ is the annual amount of water in acre feet used for production by all sectors. Let $\mathrm{W}$ be the total water available in acre feet in a year for two competing uses: economic production and cui-ui preservation. Then, $W=W_{E}+W_{C}$, where $W_{C}$ is the annual amount of water in acre feet used for cui-ui preservation. If $W_{C M}$ is the minimum level of water feet allocated for cui-ui under the federal mandate in a year, then $W_{E M}=W-W_{C M}$ is the maximum annual amount of water available for production by sectors in the region.

Let $t$ be the amount of water transferred in acre feet from economic uses to cui-ui preservation in a year. The allocation of water becomes:

$$
\begin{aligned}
& \mathrm{W}_{\mathrm{E}}=\mathrm{W}_{\mathrm{EM}}-\mathrm{t}, \\
& \mathrm{W}_{\mathrm{C}}=\mathrm{W}_{\mathrm{CM}}+\mathrm{t} .
\end{aligned}
$$

The economic cost of this water transfer is measured by the difference between the maximum economic output $\left(\mathrm{Q}_{M}\right)$ produced at $\mathrm{W}_{\mathrm{EM}}$ and the output $(\mathrm{Q})$ produced at $W_{E}$. That is:

$$
C=\Delta Q=Q_{M}-Q=Q_{M}-f\left(W_{E}\right)
$$

Following standard microeconomic theory, production occurs at the second stage of the general production curve. That is:

$$
\frac{d f\left(W_{E}\right)}{d W_{E}} \geq 0,
$$




$$
\frac{d^{2} f\left(W_{E}\right)}{d W_{E}^{2}} \leq 0
$$

Since $W_{E}=W_{E M}-t$, then:

$$
C=Q_{M}-f\left(W_{E}\right)=Q_{M}-f\left(W_{E M}-t\right)=C(t),
$$

and

$$
\begin{aligned}
& \frac{d C}{d t} \geq 0 \\
& \frac{d^{2} C}{d t^{2}} \geq 0
\end{aligned}
$$

Hence, the economic cost function is positively sloped and convex with respect to water transfer.

\section{Cui-ui Survival Probability Function}

The survival probability of cui-ui depends on the cui-ui population size,

$$
\mathrm{S}=\mathrm{S}(\mathrm{P})
$$

where $S$ is the cui-ui survival probability and $P$ is the cui-ui population size. $S(P)$ is an increasing function of $P$, i.e., $d S / d P>0$. Cu-ui population size itself, however, depends on water level:

$$
\mathbf{P}=\mathbf{P}\left(\mathbf{W}_{\mathrm{C}}\right)
$$

Similarly, $P\left(W_{C}\right)$ is an increasing function of $W_{C}$, i.e., $d P / d W_{C}>0$.

Substituting $P$ and $W_{C}=W_{C M}+t$ into the $S$ function, one gets:

$$
\begin{aligned}
& \mathrm{S}=\mathrm{S}(\mathrm{P})=\mathrm{S}\left[\mathrm{P}\left(\mathrm{W}_{\mathrm{C}}\right)\right]=\mathrm{S}\left[\mathrm{P}\left(\mathrm{W}_{\mathrm{CM}}+\mathrm{t}\right)\right]=\mathrm{S}(\mathrm{t}), \\
& \frac{d S}{d t}>0 .
\end{aligned}
$$

This equation shows a positive relationship between cui-ui survival probability (S) and water transfers (t). 


\section{Cost Function of Cui-ui Preservation}

As shown above, both the economic cost function and cui-ui survival probability are positively related to water transfers. Combining these results, an economic cost function of cui-ui survival probability can be derived as follows:

$$
\begin{aligned}
& \mathrm{C}=\mathrm{C}[\mathrm{t}(\mathrm{S})]=\mathrm{C}(\mathbf{S}), \\
& \frac{d C}{d S}=\frac{d C}{d t} \frac{d t}{d S}>0 .
\end{aligned}
$$

where $t(S)$ is the inverse of the cui-ui survival probability function that maps the water transfer required to assume a given probability of species survival. These equations relate the economic cost to cui-ui survival probability (S) and show that this relationship is positive. There is a trade-off between economic output and cui-ui survival probability. In order to increase cui-ui survival probability, economic output will have to be reduced. A priori, the shape of the cost function $\mathrm{C}(\mathrm{S})$ cannot be determined. Generally, the shape of $\mathrm{C}(\mathrm{S})$ could be convex because $C(t)$ is convex. But if $t(S)$ is concave and its concavity outweighs the convexity of $C(t)$, the cost function $C(S)$ could be concave. The shape of $C(S)$ is therefore determined by the empirical behavior of the functions $C(t)$ and $t(S)$.

\section{ESTIMATION OF THE COST FUNCTION FOR CUI-UI PRESERVATION}

The study area covers parts of Eastern California and Western Nevada. The California portion covers parts of Sierra County, Nevada County, Placer County, El Dorado County, and Alpine County. The Nevada portion covers parts of Pershing County, Storey County, Washoe County, Lyon County, Carson city (Nevada's capital), and Douglas County. We refer to this region as Northwestern Nevada in discussing the results throughout the paper. A map of the study area is provided in Figure 1.

Estimation of the cost function for cui-ui preservation, $C=C(S)$, is a three-step process: (i) estimating the cui-ui survival probability function for various water levels, $S=S(t)$, (ii) estimating the economic cost function that relates the cost of producing a given output level by an economic sector, $C=C(t)$, and (iii) combining $S(t)$ and $C(t)$ to estimate the cost function of cui-ui preservation, $C=C(S)$. The estimation results of the functions $S=S(t), C=C(t)$, and $C=C(S)$ are presented in the next three sub-sections, respectively. 


\section{FIGURE 1}

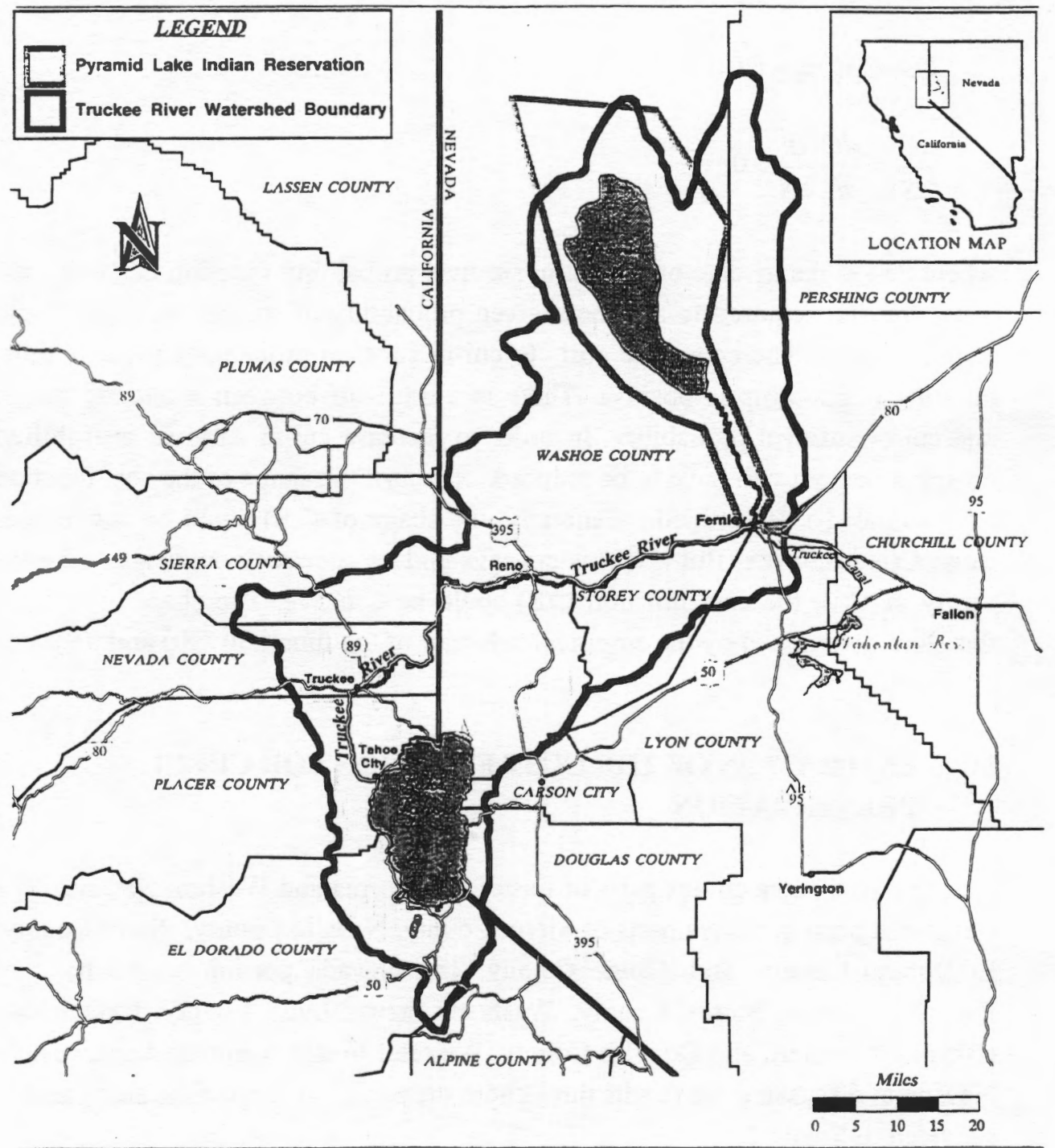

Note: Provided by the Burcau of Business and Economic Research, Universiry of Nevada, Reno. 


\section{Estimation of the Cui-ui Survival Probability Function: $\mathbf{S}(\mathbf{t})$}

The cui-ui survival probability function, $S=S(t)$, derived in section III, is a pivotal piece in estimating the cost of water transfer for cui-ui survival. An important part of the Cui-ui Recovery Plan is the modeling of the cui-ui population (U.S. Fish and Wildlife Service, 1992). The cui-ui population model projects probable spawning success of cui-ui, based on aspects of their reproductive biology and probable survivorship in the lake. These sequences are then repeated for a large number of independent samples to give the cui-ui survival probability for the 200-year duration of the stochastic streamflow simulation.

The cui-ui population model used in this study, developed by Buchanan and Strekal (1988), compares the possible effects of various water management plans on cui-ui population dynamics. The model synthesizes hydrological data, known and attributed biological characteristics and population dynamics of cui-ui to simulate the reproductive response of the cui-ui population to varying instream flow and Pyramid Lake elevation over time. It is a single-species time-series model that combines the basic elements of the Leslie matrix model, a discrete time-age structure model, and a model of fluctuating river habitat availability and fish requirement (Bovee, 1982; Begon and Mortimer, 1986). These elements are combined further with environmental characteristics unique to the Truckee River/Pyramid Lake system and behavioral characteristics of cui-ui.

The population model simulates the number of yolk-sac larvae recruited to the population each year, i.e., new year class, and the number of individuals remaining in each year class by incorporating the following parameters: river access; attraction flows; instream flow/temperature relation; fecundity rates; egg viability; temperature tolerance of eggs; annual mortality rates; and population size. Specifically, the number of cui-ui that survives out of 1,000 eggs (yolk-sac larvae), called the larvae survival rate (LSR), determines the outcome of cui-ui survival probability for a given level of water transfer ( $t)$. In addition to biological factors, the LSR is also a function of the amount of water allocated for cui-ui preservation. Moreover, the LSR is a shift factor of the cui-ui survival probability function, i.e., $S=S[t, L S R(t)]$. The model tracks only female cui-ui because female numbers are the limiting factor in the cui-ui population by influencing egg viability and production.

Simulations are run to identify the amount of supplementary water needed for recovery. Two hundred stochastic traces are used to derive the cui-ui model utilizing the lower estimate 0.001 , the upper estimate 0.003 , and the intermediate "best" estimate 0.002 , of the LSR. Supplementary water was added into the system beginning in the first year of simulation in 1991. The results of these 
simulations, the estimates of the cui-ui survival probability function for three values of the LSR, are shown in Table 2. As the results indicate, cui-ui survival probability increases substantially as the LSR rises from 0.001 to 0.003 for a given level of water transfer.

TABLE 2

Estimates of Cui-ui Survival Probability for Various Levels of Water Allocation

Water Transfer in Acre Feet $\quad$ LSR $=0.001 \quad$ LSR $=0.002 \quad$ LSR $=0.003$

$\begin{array}{cccc}0 & 0.20 & 0.50 & 0.75 \\ 3,000 & 0.23 & 0.53 & 0.78 \\ 5,000 & 0.25 & 0.55 & 0.79 \\ 10,000 & 0.29 & 0.59 & 0.82 \\ 15,000 & 0.33 & 0.63 & 0.85 \\ 40,000 & 0.51 & 0.85 & 0.94 \\ 45,000 & 0.53 & 0.87 & 0.95 \\ 70,000 & 0.68 & 0.95 & 0.99 \\ 100,000 & 0.85 & 0.98 & 0.99 \\ 120,000 & 0.95 & 1.00 & 1.00\end{array}$

The uncertainty in the value of larvae survival rate is reflected in the difference between probabilities from the cui-ui survival probability function for the LSR of $0.001,0.002$, and 0.003 for a given level of water allocation. For example, if one wants to be 68 percent sure that cui-ui survives at the LSR 0.001 , then the amount of water transfer, $t$, must equal 70,000 acre feet. On the other hand, with water transfer at 70,000 acre feet, a much higher probability of cui-ui survival, 95 percent, can be achieved at the LSR 0.002 .

\section{Estimation of the Economic Cost Function: $\mathbf{C}(t)$}

The economic cost function, $\mathrm{C}(\mathrm{t})$, developed in section III, provides the cost of a given amount of water transfer for cui-ui preservation. In this study, an input-output (IO) model is used to estimate the dollar values of the reduced economic sectors' output in the region of the study due to water transfers. ${ }^{3}$ This IO model is a component of the Truckee River Basin Regional Economic Impact Model (1995).

In applying the IO model, 13 sectors within the economy are identified. These sectors are aggregation of individual business enterprises, firms, or activities which produce the same or similar products, or which purchase the same inputs to use in production. Table 3 presents definitions of each economic 


\section{TABLE 3}

Definition of Economic Sectors

Input-Output Model of Northwestern Nevada

\section{Economic Sector}

Agricultural Production

Agricultural Services

Mining

Construction

Manufacturing

Transportation and Communications

Utilities

Trade

Finance, Insurance, and Real Estate

Services

Hotels and Gaming

Local Government

Households
Definition

Production of livestock, dairy, alfalfa hay, other hay, and barley.

Veterinary services, landscape, and horticultural service.

Mining of gold and sliver ores, geothermal energy, diatomaceous earth, clay, and gravel.

General building, heavy construction, and special trade contractors.

Manufacturing of food products, wood products, furniture, paper products, printing, publishing, chemical products, petroleum products, plastic products, stone products, clay products, glass products, fabricated metal products, industry equipment, electronic equipment, transportation equipment, and instruments.

Railroad and air transportation, trucking, warehousing, passenger transit, transportation services, and communications.

Electric, gas, and sanitary services.

Wholesale and retail trade.

Depository and non-depository institutions, security brokers, commodity brokers, insurance carriers, insurance agents, insurance brokers, real estate, and investment offices.

Personal services, business services, repair services, motion pictures, recreation, legal services, educational services.

Hotel, casinos, and recreation services.

Activities of all local government entities.

Consumers.

sector, agriculture and non-agriculture. The agriculture sector includes production of livestock, dairy, alfalfa hay, other hay, barley, and agricultural services. The non-agriculture sector includes mining, construction, manufacturing, transportation and communications, utilities, trade, finance, insurance, and real estate, services, hotels and gaming, local government, and households. The categorization of these sectors is based on standard industrial 
classification (SIC) codes taken from the Standard Industrial Classification Manual.

The IO model is estimated using the 1993 data collected for output, employment, and water use of each of the thirteen economic sectors. ${ }^{4}$ Additionally, data on income, population, and housing in the study region were also collected and used. The estimates of the economic cost function, $C(t)$, along with the estimates of the employment reduction, are presented in Table 4. Since derivation of the cui-ui preservation cost function is the main objective of the present study, the results of the estimates of output reduction due to water transfers are only discussed below.

Table 4 reports the dollar value of the reduced outputs of the thirteen economic sectors in Northwestern Nevada due to a given level of water transfer for cui-ui preservation. For a 3,000 acre feet of water transfer per year, the dollar value of the reduced output ranges from $\$ 113,728$ for agricultural production to $\$ 59,413,071$ for households, totaling $\$ 243,278,664$ for all economic sectors. As expected, reduced output cost of economic sectors increases substantially as the level of water transfer rises to a larger acre feet. For example, the dollar value of the reduced output goes up to $\$ 4,548,891$ for agricultural production and to $\$ 2,376,403,654$ for households when there is a water transfer of 120,000 acre feet per year, totaling $\$ 9,730,658,555$ for all economic sectors.

Table 5 presents the cost of each economic sector due to water transfer for cui-ui preservation as a percentage of the baseline output dollar value for various water transfers. The employment results are also reported for each sector in Table 5. The percentages are fairly moderate for a 3,000 acre feet of water transfer, ranging from less than 1 percent for households to slightly over 2 percent for agricultural production. For a 15,000 acre feet of water transfer, the economic cost of each sector rises significantly. Agricultural production and utilities have the largest percentage drop of almost 11 percent, i.e., their reduced output dollar value is about 11 percent of their baseline output dollar value. The smallest percentage drop is over 4 percent, for households. As expected, economic costs to the sectors for a 120,000 acre feet of water transfer are significant. Again, agricultural production and utilities face the most severe costs because both sectors are heavily dependent on water input in their production. They lose over 87 percent of their baseline output dollar value as a result of the reduced output due to water transfer. The least impacted sector is households, losing almost 36 percent of the dollar value of its baseline output when there is a 120,000 acre feet of water transfer.

The results, presented in Tables 4 and 5, confirm the existence of a rather steep positively-sloped economic cost function for incremental levels of water transfer. The results from the previous two sub-sections, i.e., the estimates of the 


\section{TABLE 4}

Estimates of the Reduced Output Dollar Value and the Reduced Employment of Economic Sectors in Northwestern Nevada Due to Water Transfer for Cui-ui Preservation

\begin{tabular}{lccc}
\hline Economic Sector & 3,000 acre feet & 15,000 acre feet & 120,000 acre feet \\
\hline Agricultural Production & $\$ 113,728$ & $\$ 568,640$ & $\$ 4,548,891$ \\
& $(2)$ & $(9)$ & $(69)$ \\
Agricultural Services & 755,662 & $3,778,309$ & $30,224,954$ \\
Mining & $(12)$ & $(62)$ & $(499)$ \\
Construction & 842,656 & $4,213,278$ & $33,704,534$ \\
& $(16)$ & $(79)$ & $(638)$ \\
Manufacturing & $20,763,933$ & $103,819,666$ & $830,515,674$ \\
& $(226)$ & $(1,131)$ & $(9,054)$ \\
Transportation and Communications & $19,757,940$ & $98,789,700$ & $790,277,967$ \\
Utilities & $(186)$ & $(933)$ & $(7,464)$ \\
& $12,068,988$ & $60,344,939$ & $482,735,300$ \\
Trade & $(132)$ & $(662)$ & $(5,295)$ \\
& $9,403,718$ & $47,018,591$ & $376,129,862$ \\
Finance, Insurance, and Real Estate & $(58)$ & $(294)$ & $(2,359)$ \\
Services & $28,880,742$ & $144,403,712$ & $1,155,171,758$ \\
& $(407)$ & $(2,038)$ & $(16,310)$ \\
Hotels and Gaming & $25,390,977$ & $126,954,884$ & $1,015,588,135$ \\
& $(315)$ & $(1,579)$ & $(12,635)$ \\
Local Government & $36,719,210$ & $183,596,052$ & $1,468,694,756$ \\
Households & $(499)$ & $(2,499)$ & $(19,993)$ \\
& $17,377,486$ & $86,887,428$ & $695,064,563$ \\
& $(263)$ & $(1,319)$ & $(10,557)$ \\
\hline Total & $11,790,554$ & $58,952,770$ & $471,598,504$ \\
& $(190)$ & $(951)$ & $(7,601)$ \\
& $59,413,071$ & $297,065,355$ & $2,376,403,654$ \\
& $(0)$ & $(0)$ & $(0)$ \\
\hline & & & \\
\hline & $\$ 243,278,664$ & $\$ 1,216,393,322$ & $\$ 9,730,658,555$ \\
& $(2,306)$ & $(11,556)$ & $(92,474)$ \\
\hline
\end{tabular}

Notes: Numbers in parentheses are the estimated employment reduction of each sector due to a given level of water transfer ( $t$ ). For the purpose of brevity, the results for all levels of water transfer to cui-ui preservation are not reported in the table. The results for $5,000,10,000,40,000,45,000,70,000,100,000$, and 110,000 acre feet of water transfer are available from the authors upon request. In the 10 model used here, households are a consumption sector and that is why the employment effect of water transfer for this sector is zero. The estimated output and employment effects of water transfer are based on output and employment multipliers of each sector. These multipliers are available from the authors upon request.

cui-ui survival probability function, $S=S(t)$, and the economic cost function for water transfer, $\mathrm{C}=\mathrm{C}(\mathrm{t})$, are the basis for deriving cost function estimates for cui-ui preservation, $\mathrm{C}=\mathrm{C}(\mathbf{S})$, presented in the sequel.

\section{Estimation of The Cost Function of Cui-ui Preservation: C(S)}

The cost function of cui-ui preservation, C(S), developed in section III, provides the economic cost of achieving a higher cui-ui survival probability. It is 


\section{TABLE 5}

Estimates of the Reduced Output Dollar Value and the Reduced Employment as a Percentage of the Respective Baseline Output Dollar Value and Baseline Employment of Economic Sectors in Northwestern Nevada Due to Water for Cui-ui Preservation

\begin{tabular}{|c|c|c|c|}
\hline Economic Sector & $\begin{array}{c}3,000 \\
\text { Acre Feet }\end{array}$ & $\begin{array}{c}15,000 \\
\text { Acre Feet }\end{array}$ & $\begin{array}{c}120,000 \\
\text { Acre Feet }\end{array}$ \\
\hline Agricultural Production $[\$ 5,215,455 ; 101]$ & $\begin{array}{l}2.18 \% \\
(1.7 \%)\end{array}$ & $\begin{array}{l}10.90 \% \\
(8.51 \%)\end{array}$ & $\begin{array}{l}87.22 \% \\
(68.1 \%)\end{array}$ \\
\hline Agricultural Services $[\$ 52,687,679 ; 1,347]$ & $\begin{array}{c}1.43 \\
(0.93)\end{array}$ & $\begin{array}{c}7.17 \\
(4.63)\end{array}$ & $\begin{array}{c}57.37 \\
(37.06)\end{array}$ \\
\hline Mining $[\$ 66,086,430 ; 1,739]$ & $\begin{array}{c}1.28 \\
(0.92)\end{array}$ & $\begin{array}{c}6.38 \\
(4.60)\end{array}$ & $\begin{array}{c}51.00 \\
(36.79)\end{array}$ \\
\hline Construction $[\$ 1,440,667,287 ; 12,555]$ & $\begin{array}{c}1.44 \\
(1.80)\end{array}$ & $\begin{array}{c}7.21 \\
(9.01)\end{array}$ & $\begin{array}{c}57.65 \\
(72.12)\end{array}$ \\
\hline Manufacturing $[\$ 1,363,431,322 ; 11,248]$ & $\begin{array}{c}1.45 \\
(1.65)\end{array}$ & $\begin{array}{c}7.25 \\
(8.30)\end{array}$ & $\begin{array}{c}57.96 \\
(66.36)\end{array}$ \\
\hline $\begin{array}{l}\text { Transportation and Communications } \\
{[\$ 739,238,624 ; 8,729]}\end{array}$ & $\begin{array}{c}1.63 \\
(1.52)\end{array}$ & $\begin{array}{c}8.16 \\
(7.58)\end{array}$ & $\begin{array}{c}65.30 \\
(60.66)\end{array}$ \\
\hline Utilities [\$430,242,000; 2,693] & $\begin{array}{l}2.19 \\
(2.19)\end{array}$ & $\begin{array}{c}10.93 \\
(10.93)\end{array}$ & $\begin{array}{c}87.42 \\
(87.42)\end{array}$ \\
\hline Trade $[\$ 1,718,152,972 ; 36,174]$ & $\begin{array}{c}1.68 \\
(1.13)\end{array}$ & $\begin{array}{c}8.40 \\
(5.63)\end{array}$ & $\begin{array}{c}67.23 \\
(45.10)\end{array}$ \\
\hline $\begin{array}{l}\text { Finance, Insurance, and Real Estate } \\
\qquad[\$ 1,381,758,827 ; 15,612]\end{array}$ & $\begin{array}{c}1.84 \\
(2.02)\end{array}$ & $\begin{array}{c}9.19 \\
(10.12)\end{array}$ & $\begin{array}{c}73.50 \\
(80.93)\end{array}$ \\
\hline Services $[\$ 1,873,070,458 ; 34,927]$ & $\begin{array}{c}1.96 \\
(1.43)\end{array}$ & $\begin{array}{c}9.80 \\
(7.16)\end{array}$ & $\begin{array}{c}78.41 \\
(57.24)\end{array}$ \\
\hline Hotels and Gaming $[\$ 1,361,938,251 ; 25,643]$ & $\begin{array}{c}1.28 \\
(1.03)\end{array}$ & $\begin{array}{c}6.38 \\
(5.14)\end{array}$ & $\begin{array}{c}51.03 \\
(41.17)\end{array}$ \\
\hline Local Government $[\$ 704,232,921 ; 12,458]$ & $\begin{array}{c}1.67 \\
(1.53)\end{array}$ & $\begin{array}{c}8.37 \\
(7.62)\end{array}$ & $\begin{array}{c}66.97 \\
(61.02)\end{array}$ \\
\hline Households $[\$ 6,720,549,054 ; 0]$ & $\begin{array}{l}0.88 \\
(0)\end{array}$ & $\begin{array}{l}4.42 \\
(0)\end{array}$ & $\begin{array}{l}35.36 \\
(0)\end{array}$ \\
\hline
\end{tabular}

Notes: Numbers in brackets are the respective baseline output dollar value and baseline employment of each economic sector. Also see notes to Table 4. 
TABLE 6

Estimates of the Cost Function of Cui-ui Preservation

Water Level in Acre Feet Estimated Dollar Value of the Cui-ui Survival Probability Reduced Output

$(\mathrm{LSR}=0.002)$

$\begin{array}{crll}3,000 & \$ 243,278,664 & {[1.36 \%]} & 0.53 \\ 5,000 & 405,545,778 & {[2.27]} & 0.55 \\ 10,000 & 810,847,544 & {[4.54]} & 0.59 \\ 15,000 & 1,216,393,322 & {[6.81]} & 0.63 \\ 40,000 & 3,243,634,189 & {[18.16]} & 0.85 \\ 45,000 & 3,648,935,955 & {[20.44]} & 0.87 \\ 70,000 & 5,676,176,822 & {[31.78]} & 0.95 \\ 100,000 & 8,108,719,455 & {[45.41]} & 0.98 \\ 120,000 & 9,730,658,555 & {[54.49]} & 1.00\end{array}$

Note: Numbers in brackets are the reduced output dollar value of all sectors in Northwestern Nevada, resulting from a given level of water transfer to cui-ui, as a percentage of the sectors' total baseline output dollar value.

the combination of the cui-ui survival probability function, $S(t)$, and the economic cost function, $C(t)$. Table 6 presents cui-ui preservation cost function estimates, $C(S)$, using the respective estimation results of the functions $S(t)$ and $C(t)$, shown in Table 2 and partly in Table 4.

As a reference point, the levels of water transfers in acre feet are provided in the first column of Table 6 . The estimated dollar values of the reduced outputs of the thirteen sectors, as a result of water transfer for cui-ui preservation, are presented in the second column of Table 6. Additionally, the dollar values of the reduced outputs of all sectors, as percentages of the dollar values of the sectors' total baseline outputs, are also reported in the second column. Finally, the last column presents the cui-ui survival probability based on the "intermediate" estimate of 0.002 of the larvae survival rate.

A cui-ui survival probability of 53 percent, achieved at an early stage of a water transfer scenario of 3,000 acre feet, results in an estimated dollar value of $\$ 243,278,664$ in reduced output for all sectors. It is almost 1.4 percent of the sectors' total baseline output. An increase of 2 percent in survival probability of cui-ui to 55 percent requires an increase of 2,000 acre feet in water transfer, resulting in an increase of $\$ 162,267,114$ in the estimated reduced output value for all sectors. This dollar value is an approximate marginal cost estimate of obtaining a 2 percent higher cui-ui survival probability when the water transfer is 3,000 acre feet per year. 
FIGURE 2

Marginal Cost Curve for Cui-ui Survival

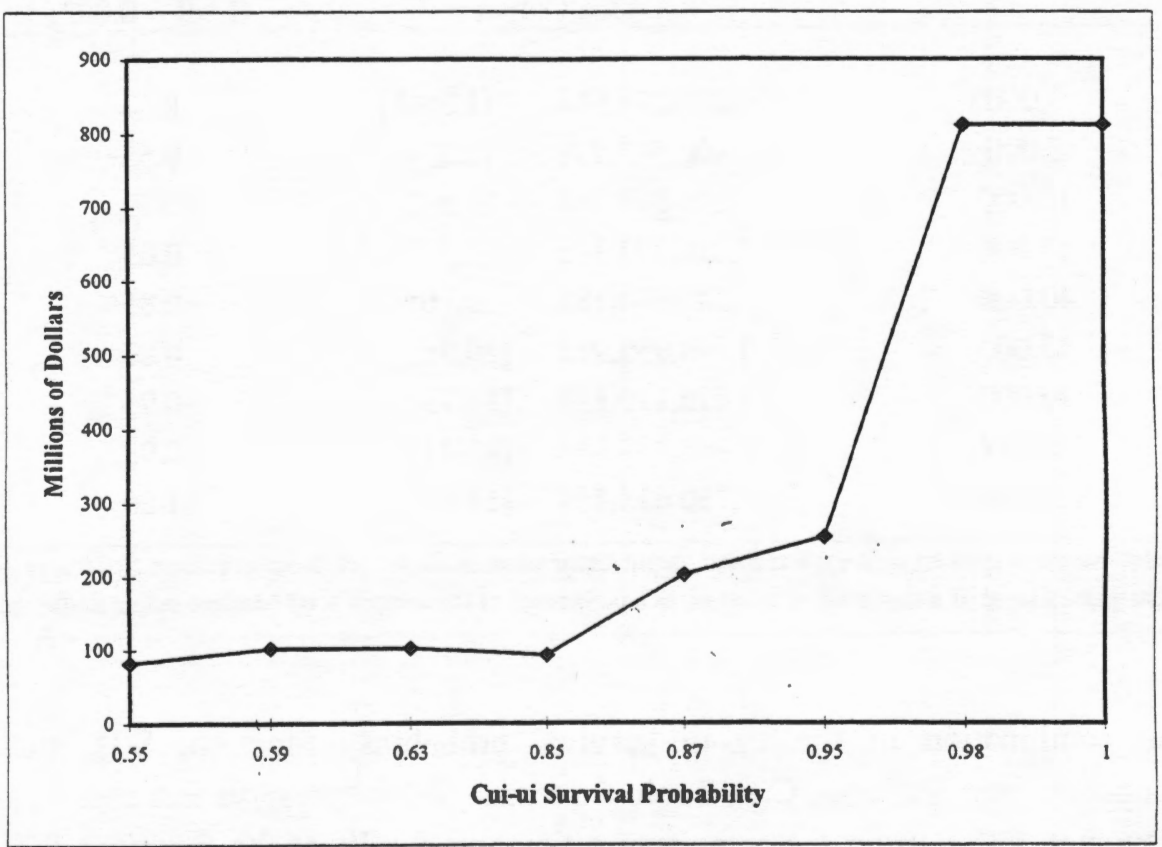

A medium amount of water transfer at 15,000 acre feet provides a high cui-ui survival probability of 63 percent, resulting in an estimated dollar value of $\$ 1,216,393,322$ due to the reduced output in all sectors, almost 7 percent of the sectors' total baseline output. A twenty two percent increase in cui-ui survival probability from 63 to 85 percent requires a 25,000 acre feet increase in water transfer, leading to a $\$ 2,027,240,867$ increase in the estimated reduced output value for all sectors.

For a higher amount of water transfer to gain a higher cui-ui survival probability, e.g., 70,000 or 100,000 or 120,000 acre feet, the resulting increase in the estimated reduced output value in all sectors is significant. For the water transfer increase from 70,000 to 100,000 acre feet and from 100,000 to 120,000 acre feet, the respective incremental costs are $\$ 2,432,542,633$ and $\$ 1,621,939,400$, with respective gains in cui-ui survival probability of 3 and 2 percent. 
The estimates of the cost function $\mathrm{C}(\mathrm{S})$ in Table 6 are also used to derive a cui-ui preservation marginal cost curve, shown in Figure 2. The marginal cost curve has a relatively flat slope for approximately up to 0.85 cui-ui survival probability, and a steep slope for cui-ui survival probability over 0.85, confirming the enormous cost of achieving cui-ui survival with certainty. A substantial increase in the reduced output value, as a percentage of the sectors' total baseline output dollar value, secures a higher cui-ui survival probability.

The above findings provide evidence to support the trade-off between economic production and an endangered species preservation, suggesting that the level of species survival certainty is the appropriate policy choice variable, rather than the simplistic binary problem of species preservation or extinction. Instead of measuring the cui-ui survival total cost, one should consider the incremental cost of preservation efforts. The results should also help policy makers to evaluate the opportunity cost of Northwestern Nevada cui-ui preservation. An appropriate economic model, however, needs to assess both the marginal cost and marginal benefit of cui-ui preservation. This study only provides estimates on marginal cost. It calls for future research to determine marginal benefit estimates of cui-ui preservation.

\section{CONCLUSION}

The economics of biodiversity is gaining popularity in both academic and policy-oriented arenas by investigating the conceptual link between a particular species' contribution to biodiversity and the cost of efforts to save that species. In this study, an integrative approach is chosen to examine the economic cost of endangered species preservation: the Northwestern Nevada cui-ui. Models of cui-ui survival probability and economic cost of water transfer are developed to estimate the economic cost of cui-ui preservation. In estimating the cui-ui survival probability, a cui-ui population model compares the possible effects of various water management plans on cui-ui population dynamics. The cui-ui population model synthesizes hydrological data, known and attributed biological characteristics, and population dynamics of cui-ui, to simulate the reproductive response of the cui-ui population to varying instream flow and Pyramid Lake elevation over time. The water transfer cost is estimated using the IO model component of the Truckee River Basin Regional Economic Impact Model to determine the economic sectors' reduced output value in Northwestern Nevada due to water transfer for cui-ui preservation.

Our results provide the cost estimates to secure a higher cui-ui survival probability. A cost of over 160 million dollars increases the cui-ui survival 
probability by 2 percent, from 53 to 55 . Over 2 billion dollars is necessary to increase the cui-ui survival probability by 22 percent, from 63 to 85 . The cost to gain a higher cui-ui survival probability stays well over 2 billion dollars at the likelihood levels above 87 percent, confirming the enormous cost of achieving cui-ui survival with certainty.

The results reported here might overstate cui-ui preservation costs for three reasons. First, water transfer increases water flow in the lower Truckee River and water level in Pyramid Lake, providing some external economic benefits to the region. For example, water-related recreation activities could become more popular. Second, increasing water flow and level can also improve ecological preservation along the lower Truckee River and in the Pyramid Lake. Last, cui-ui preservation costs are estimated by using a larvae survival probability of 0.002 . Increasing water level in the lower Truckee River and Pyramid Lake could improve fish passage as well as larvae survival probability and reducing economic costs. Incorporation of all these factors into an economic analysis of cui-ui preservation calls for future studies.

\section{ENDNOTES}

1. The location of Pyramid lake and the area of the study are provided in the map in Figure 1.

2. A water year runs from October through September.

3. Following a reviewer's suggestion, the estimates of the reduced employment of the economic sectors due to water transfer are also being provided.

4. The respective baseline water use in the IO model used in the present study for agriculture, commercial, and residential sectors is 73,$696 ; 12,432$; and 72,453 acre feet.

\section{REFERENCES}

Begon, M., and M. Mortimer. Population Ecology - A Unified study of Animals and Plants. 2nd ed., Blackwell Scientific Publications, 1986.

Bovee, K. "A Guide to Stream Habitat Analysis Using the Instream Flow Incremental Methodology." Cooperative Instream Flow Service Group, Instream Flow Information Paper No. 12, 1982. 
Buchanan, C., and T. Strekal. "Simulated Water Management and Evaluation Procedures for Cui-ui (Chasmistes cujus)." U.S. Fish and Wildlife Service, Great Basin Complex. Reno, Nevada, 1988.

Coleman, M., C. Buchanan, and H. Burge. "Spawning Runs From Pyramid Lake in 1986 and Studies of Cui-ui Life History." U.S. Fish and Wildlife Service, Great Basin Complex. Reno, Nevada, 1987.

Gowdy, J. "The Value of Biodiversity: Markets, Society, and Ecosystems." Land Economics. 73 (1997): 25-41.

Gowdy, J., and C. McDaniel. "One World, One Experiment: Addressing the Biology-Economics Conflict." Ecological Economics. 14 (1995): 180-192.

Kahn, J., and M. Kemp. "Economic Losses Associated with the Degradation of an Ecosystem: The Case of Submerged Aquatic Vegetation in Chesapeake Bay." Journal of Environmental Economics and Management. 12 (1985): 246-263.

Koch. D. "Reproductive Characteristics of the Cui-ui Lakesucker (Chasmistes cujus Cope) and Its Spawning Behavior in Pyramid Lake, Nevada." Transactions of the American Fisheries Society. 102 (1973):145-149.

LaRivers, I. "Fish and Fisheries of Nevada." Nevada Fish and Game Commission, 1962.

Montgomery, C., G. Brown, and D. Adams. "The Marginal cost of Species Preservation: The Northern Spotted Owl." Journal of Environmental Economics and Management. 26 (1994): 111-28.

Scoppettone, G., M. Coleman, and G. Wedemeyer. "Life History and Status of the Endangered Cui-ui of Pyramid Lake, Nevada." U.S. Fish and Wildlife Research. 1 (1986):1-23.

Scoppettone, G., and G. Vinyard. "Lakesucker Life History and Management." In W. Minckley and J. Deacon (eds). The Battle Against Extinction: Native Fish Management in the American West, University of Arizona Press, 1991. Truckee River Basin Regional Economic Model. Economic Development Center, University of Nevada, Reno, 1995.

U.S. Department of Interior. Record of Decision: Newlands Project Operating Criteria and Procedures. Washington, D.C., 1988.

U.S. Fish and Wildlife Service. Cui-ui Recovery Plan. Portland, Oregon, 1977.

U.S. Fish and Wildlife Service. Cui-ui Recovery Plan - Revision. Portland, Oregon, 1983.

U.S. Fish and Wildlife Service. Cui-ui (Chasmistes cujus) Recovery Plan. 2nd Revision, Portland, Oregon, 1992. 